\title{
Calculative Measures of Organising and Decision-Making in Developing Countries: The Case of a Quasi-Formal Organisation in Ghana
}

\begin{abstract}
Purpose: This paper examines how a "quasi-formal" organisation in a developing country engages in informal means of organising and decision-making through the use of calculative measures.

Methodology: The paper presents a case study of a large-scale indigenous manufacturing company in Ghana. Data for the study were collected through the use of semi-structured interviews conducted both onsite and off-site, supplemented by informal conversations and documentary analysis. Weber's notions of rationalities and traditionalism informed the analysis.

Findings: The paper advances our knowledge about the practical day-to-day organisation of resources and the associated substantive rational calculative measures used for decisionmaking in quasi-formal organisations operating in a traditional setting. Instead of formal rational organisational mechanisms such as hierarchical organisational structures, production planning, labour controls and budgetary practices, the organisational mechanisms are found to be shaped by institutional and structural conditions which result from historical, socio-cultural and traditional practices of Ghanaian society. These contextual substantive rational calculative measures consist of the native lineage system of inheritance, chieftaincy, trust and the power concealed within historically established sociocultural practices.

Originality: This paper is one of a few studies providing evidence of how local and traditional social practices contribute to shaping organising and decision-making activities in indigenous "quasi-formal" organisations. The paper extends our understanding of the nexus between "technical rational" calculative measures and the traditional culture and social practices prevailing in sub-Saharan Africa in general, and Ghana in particular.
\end{abstract}

Keywords: Accounting and calculative measures; Sub-Saharan Africa; Ghana; Quasi-formal organisation; Traditionalism. 


\section{Introduction}

This paper examines how a large-scale indigenous manufacturing company in Ghana engages in informal means of organising and decision-making by using calculative measures, illustrating the operation of "quasi-formal" organisations in developing countries. Quasiformal organisations are enterprises characterised by a blending between, on the one hand, formal rational structures and requirements derived from private sector management practices and, on the other hand, traditional socio-cultural practices perpetuating from generation to generation (Harriss, 1978; Guha-Khasnobis et al., 2006). While quasi-formal organisations may be less widespread in Western countries, they are an important feature of developing countries in which traditionalism (Weber, 1948) remains deeply embedded. Given the blending between formal private sector management practices and traditional cultural and social practices, it is plausible that formal and informal calculative measures co-exist in such organisations, and that these are deployed collectively in organising day-to-day activities and decision-making.

Extant accounting work has developed three main strands of research to shed light on the functioning of calculative measures in developing countries (Alawattage et al., 2017). The first strand of research, represented by scholars such as Uddin (2009) and Uddin and Choudhury (2008), has examined management accounting practices within formal structured organisations operating in traditional societies. These studies illustrate how the application of accounting measures may lead to unintended consequences in societies where Western capitalistic structures are underdeveloped. A second strand of research, represented by scholars such as Gallhofer and Chew (2000), Walker and Llewellyn (2000), Jayasinghe and Wickramasinghe (2007), Wickramasinghe and Hopper (2005), Alawattage et al., (2017) and Jayasinghe et al., (2020), has investigated the use of particular accounting practices and measurements beyond formal structured organisations, in informal settings such as rural and indigenous communities. The third strand of research pays attention to the application of private-sector rational accounting practices within formalised and bureaucratic public sector entities, predicated upon efficiency and effectiveness in improving governance and accountability and imposed at the behest of international organisations and development partners, as part of governance and accountability reforms. Scholars such as Wickramasinghe and Hopper (2005), Van Helden and Uddin (2016), Guven-Uslu et al., (2020), Hopper et al., (2017) have noted the failure to enforce the calculative measures as intended and the inability to engender the expected results - themes which recur throughout the studies undertaken in both developed and developing country contexts but especially in different developing country settings.

Notwithstanding these rich strands of research, there seems to have been a neglect of quasiformal organisations as a site for analysing the organising of day-to-day operations and decision-making using calculative measures in developing country contexts Rarely have accounting studies investigated how rational calculative measures might operate in quasiformal organisations, despite these being perhaps the most widespread forms of organisations in developing country contexts in general and in sub-Sahara in particular (Harriss, 1978; Hopper et al., 2009; Guha-Khasnobis et al., 2006). Prior research (see e.g., Miller, 2001; Jayasinghe and Wickramasinghe, 2007) urges accounting researchers to examine the emergence of and ways in which, calculative measures in quasi-formal organisations shape the capacities, power relations and actions of and between individuals.

This study addresses this gap. There are at least two striking reasons why our research setting in sub-Saharan Africa is ideal for studying the use of calculative measures within quasi-formal 
organisations. First, a large number of countries in sub-Saharan Africa have, in recent decades, experienced the widespread dissemination of rational technical calculative measures and practices, such as Western-centric management accounting and control systems (MACS), at the behest of international organisations (Hopper et al., 2017). Second, traditional cultures and social practices have continued to remain influential in mediating the dynamics of organisational practices in sub-Saharan Africa (Ntiamoa-Baidu 1991; Appiah-Opoku and Hyma 1999; Chenhall, 2003). What is notable, however, is the limited knowledge about the nexus between these "technical rational" calculative measures and the traditional cultural and social practices that prevail in this region. This knowledge is critical to our understanding of the manner in which formal organisations are transformed and operationalised, under the guise of quasi-formal organisations, through the use of calculative measures.

Within sub-Saharan Africa, Ghana is a particularly compelling setting for exploring the use of calculative measures within quasi-formal organisations. Not only is Ghana an early adopter of neoliberal private management practices, which are central to the structural adjustment programmes of international development organisations (Rahaman et al., 2007), but traditionalism in Ghana has survived in everyday life in various forms, including chieftaincy, land ownerships and production (Grier, 1981). Prior studies have documented the impact of the neoliberal agenda on Ghana's economic development strategy and its consequences on society over the last three decades (Rahaman et al., 2007; Tsamenyi, et al., 2010; Alawattage and Azure, 2019). Despite this neoliberal agenda, chieftaincy as a traditional Ghanaian institution, as well as, some traditional practices (e.g. native tenure system of inheritance), have survived the historical, economic and political transformations and their influence pervades the fabric of local organisations (Grier, 1979).

Using the case study of a large-scale indigenous manufacturing company, this paper empirically investigates how Ghanaian traditional culture and social practices traverse the boundaries of indigenous companies, and in turn, create managerial dispositions and "substantive rational" organising and decision-making through the use of calculative measures. Weberian notions of "traditionalism" and "rationality" (Weber, 1948, 1958, 1961, 1968) have enabled us to engender insights into the substantive rational aspects of indigenous quasi-formal organisations, thus also making them visible.

The article proceeds as follows. Section 2 reviews related literature on the use of calculative measures in formal and informal organisational settings with an emphasis on developing countries. Section 3 provides a theoretical discussion on the Weberian notions of traditionalism and rationality (Weber, 1948, 1958, 1961, 1968) and Weber's three layers of analyses (Colignon and Covaleski, 1991) to provide the basis for analysing the calculative practices of the researched company. Section 4 outlines our research methods. The main findings of the study are presented in three sections as follows. Section 5 analyses features of the case study company and its associated traditional foundations to elaborate on the notion of quasi-formal organisations. The next two sections examine the layers of traditionalism and rationality that impact the organising and decision-making of the researched company, presenting first the external layers (section 6) and then the internal layer of analysis (section 7). Section 8 concludes, bringing out the empirical, theoretical and policy-related implications of the findings and delineates areas for future research. 


\section{Organisational calculative practices literature}

Historically, calculative practices have been mainly studied within formal organisations to examine the process of labour control and the construction of a new form of "governable person" (Miller and O'Leary, 1987; Vollmer, 2003). With the ascendency of interpretative and critical research in the last few decades, increasing attention has been devoted to understanding the role of calculative practices in the functioning of both organisations and society (Hopwood and Miller, 1994; Hopwood, 1983; Miller, 1994, 1998). For instance, how calculative practices have enabled formal organisations, to both represent and construct a particular version of reality, thereby masquerading the social consequences of their activities over the profits and welfare engendered to investors, have been widely discussed in prior work (Hines, 1988; Hopwood and Miller, 1994; Vollmer, 2003; Sikka, 2015). Considering the power of calculative practices, interpretative and critical accounting researchers have emphasised the importance of understanding the emergence of new calculative practices and the way such practices are implicated in power dynamics, agency and control in formal organisations as well as in the wider society (Covaleski et al., 1996; Miller, 2001; Vollmer, 2003; Lapsley et al., 2020).

In the context of developing countries, existing work shows that different forms of calculative measures, mainly management accounting techniques, evolved in formal organisations during the 1990s, following market capitalisation emanating from the World Bank and the IMF structural adjustment programmes (Hopper et al., 2009, 2017). Implicit within market capitalisation lies the ideas of promoting internal efficiency, coordination, control and competition, the implementation of which are considered paramount to improve performance and profitability. The key calculative measures adopted by formal organisations in developing countries include activity-based costing, balanced scorecards, capital budgeting and various performance measurement systems (Hopper et al., 2009).

However, Western-led calculative practices anchored in individualism and emphasising contracts between agents and principals, are plausibly unsuitable for the collectivist cultures that prevail in developing countries. For instance, in their study of Malaysian companies, Tales and Sofian (2007) illustrate how various performance-oriented systems introduced to companies remained ineffective in replacing the value-based and mixed calculative measures that existed beyond budgeting. Similar results, showing how calculative techniques incorporated to adhere to market capitalism fail to displace the culturally attuned calculative practices, are evident in countries such as India, Brazil and Palestine (Anderson and Lanen, 1999; Guerreiro et al., 2006; Kattan et al., 2007). Politics and family capitalism appear to be additional factors that render certain calculative practices ineffective in formal organisations operating in developing countries. In an early study, Hoque and Hopper (1994) demonstrated how political interventions in a Bangladeshi jute mill reduced formal calculative practices to ritualist roles and used them for gaining external legitimacy. Alawattage and Wickramasinghe (2008) discussed the influential role that ethnic politics played in shaping calculative practices in a privatised plantation sector in Sri Lanka. Similarly, Uddin (2009) and Uddin and Choudhury (2008) illustrated cases of formal organisations in Bangladesh where rational calculative measures were used to reinforce family capitalism rather than serving general shareholders.

A stream of critical accounting research has explored the use of calculative practices beyond formal organisations, focusing on rural and indigenous communities. For instance, in their study of a poor rural community in the Sri Lankan village of Kalamatiya, Jayasinghe and Wickramsinghe (2007) demonstrate how the community was engaged in certain calculative 
practices, and how these practices were embedded in a "total institution", defined in terms of the relations of production. Similarly, Jayasinghe and Wickramasinghe (2011) discuss the unintended consequences when the calculative logic of development accounting, prescribing a neoliberal resource allocation mechanism (claiming rural empowerment, participation, local accountability and performance evaluation), encountered the rural cultural-political logic. This resulted in the emergence of certain idiosyncrasies in resource allocation mechanisms, the outcome of which was the reconstitution of mundane calculative practices and the reproduction of rural poverty. Additionally, Alawattage (2011) shows how the presence of calculative and control practices has mediated the field-specific organisation of capital in a Sri Lankan gem mining company and performed interrelated but distinct functions of cognition, communication and domination. Overall, calculative practices embedded in informal settings tend to survive from generation to generation. Such is evident in Jayasinghe and Thomas's (2009) work, in which the authors delineate how one Sri Lankan local community preserved their indigenous calculative practices over many years, despite an ascendency in the literacy levels of community members and external pressures for change.

Extant critical accounting research discussing calculative practices in developing countries is overwhelmingly focused on public sector settings. The adoption of certain Western-led calculative measures by these countries, for instance accrual accounting and participatory budgeting, predicated on an underlying rhetoric of improved governance and accountability, have been a key focus of these studies (Rahaman, 2010; Val Helden and Uddin, 2016; Alawattage and Azure, 2019; Hopper et al., 2017). The findings of such studies are consistent in illustrating how such Western-led calculative measures have failed to appreciate the specific local, cultural and contextual factors with significant unintended consequences. While some studies demonstrate how such calculative measures have remained ineffective in practice and are merely layered with the existing measures, others emphasise their adverse impacts, such as a rise in corruption, patronage politics and neopatrimonialism (Bakre et al., 2017; Goddard and Mkasiwa, 2016; Goddard et al., 2016; Nyamori et al., 2017; Jayasinghe et al., 2020). For instance, Kuruppu et al. (2016) illustrate how participatory budgeting in a Sri Lankan urban council has resulted in political domination and symbolic violence. More recently, Alawattage and Azure (2019) have demonstrated the Ghanaian case where the calculative measures adopted to promote social accountability have served the interests of international organisations rather than the citizenry.

Informal settings in sub-Saharan Africa consist of specific social-cultural and traditional practices, which can have a profound impact on formal organisations' day-to-day operation, power dynamics and the functioning of calculative practices. For instance, in their study of a multinational subsidiary in Nigeria, Egbe et al. (2012) argue that although management control systems are built on formality, these systems tend to operate alongside informal controls. Here, informal controls (such as trust) could be more prominent than formal control mechanisms, resulting in, for example, members being assigned tasks not based on their abilities and skills but on the extent to which they are trusted by their supervisors (Jayasinghe and Thomas, 2009; Egbe et al., 2012). However, few accounting studies have investigated how specific calculative practices, both rational and traditional, are blended in organising and decision-making in formal organisations that operate in indigenous settings. Very few have investigated how these practices result in these organisations being transformed into quasi-formal organisations. Our article addresses this research gap by investigating a Ghanaian formal organisation operating in an indigenous setting. In doing so, we present a novel analysis of the distinctive and significant cultural and traditional practices that have important implications for organisational structures, production relations and calculative practices in developing countries. 


\section{Weberian notions of rationality and traditionalism}

Weber's work $(1948,1958,1961,1968)$ presents a theoretical basis that is vital in enabling us to understand how the organising and calculative decision-making practices functioning inside an indigenous organisation are framed by traditional cultures and politics. Weber's rationalities have been used in understanding the role of accounting knowledge and the accounting profession in developing capitalism (Chua and Poullaos, 1998; Auyeung and Ivory, 2003). It is argued that modern enterprises are characterised by multiple rationalities and that the distinction between formal and substantive rationality is analytically useful in generating insights into the functioning of certain practices, such as accounting practices, within enterprises (Uddin and Choudhury, 2008; Boudon, 1997; Brouwer, 2002; Mody et al., 2016).

By formal rationality, Weber means the matters of fact to a scientific and technical space of life (see also Colignon and Covaleski, 1991). Formal rationality is considered to be valueneutral and founded on an expectation that the capacity of controlling the world through calculations can be developed (Kalberg, 1980; Brubaker, 2013). On the other hand, substantive rationality is driven by a conceptual or ideological value and does not work solely as a meansend calculation of solutions to recurring problems (Aronovitch, 2012). Actions stemming from substantive rationality are, rather, guided by strong, moral and non-consequentialist reasons, which require no further justification. Uddin and Choudhury (2008) point out that Weber's work is yet to be fully exploited by accounting researchers to provide a critical and political basis for understanding accounting practices, in both traditional and capitalist societies. In this regard, our study offers an important addition to extant work, shedding light on accounting and traditionalism.

Elaborating on Weber's work, Colignon and Covaleski (1991) argue that three layers of analysis are paramount in generating a detailed understanding of organisational practices, including accounting practices. The three layers are the nature of the institutional and structural conditions (an external layer), the cultural and historical context (an external layer) and the organisational setting (internal layer). The first layer of analysis identifies the society as being replete with structural and institutional characteristics which create the conditions required for rational decision-making in organisations, such as profitability, appropriation of all physical means of production, freedom of the market, free labour, rational technology, calculable law and commercialisation of economic law (Weber, 1958). To Weber, these conditions are important in shaping capitalistic development. Weber envisages ideal-typical capitalism as having been only partially realised in the Western industrial revolutions of the eighteenth and nineteenth centuries. That said, as Uddin (2009) notes, the partial realisation of ideal-type capitalism was (and is) the result of the interactions between structural and institutional conditions and the socio-political, cultural and historical contexts, i.e. the two external layers of Weberian analysis.

The second external layer of Weberian analysis (Colignon and Covaleski, 1991) identifies specific cultural and historical features of society. These features have the propensity to facilitate or obstruct the full development of rational capitalism, the modern enterprise and rational capital accounting (Weber, 1948). Weber also recognised that capitalism has traditional forms, evident in the West, e.g. Germany until the eighteenth century, and which prevail even now in developing countries. In his work on Indian societies, Weber (1948) also mentions the destruction of intra-community relations (Demiurgie) and the elevation of an inter-community division of labour under patrimonial political domination (e.g. the caste 
system) as being a cause of the rise of traditional societies. McLane (1993) also notes that the promotion of an inter-community division of labour was an aspect of traditionalism, contradicting the money economy and capitalism as envisaged in the West, and thereby prevented the same from flourishing. These traditional forms of capitalism involve recognising and preserving the historically reproduced values, morality, norms and practices of specific social groups and communities, which leads to "conservatism in economic activities" (Weber, 1948). Weber claims that economic activities become more conservative when connected with traditional morality, and he explains how the subsequent effects of the increasing rationalisation of human life eventually traps individuals in an "iron-cage" of rule-based, rational controls. In Weber's description, "old leisurely and comfortable attitude toward life" is a key feature of traditionalism and the old form of labour in workplaces (Weber, 1948). The traditional form of labour is confined to earning just enough money to maintain a comfortable and respectable lifestyle and have a minimalist life, rather than making profits or earning more. The partial development of rational capitalism in most developing countries, or the difficulty associated with the development of ideal markets, is therefore attributed to traditionalism (Weber, 1948; Uddin, 2009), and it is perhaps not surprising that these issues are more pronounced in developing countries such as Ghana.

Weber $(1958,1961,1968)$ argues that a third, internal, layer of analysis that interacts with the first two (external) layers is needed to explore organisational practices. That is, the institutional and structural conditions, coupled with the historical and cultural features, serve as the basis for situating a specific enterprise over a period of time to analyse its organisational practices. Building on Weber's notion of rationalities, Colignon and Covaleski (1991) discussed accounting practices within the modern enterprise, a central feature of which is the existence of multiple rationalities. They argue that the existence of multiple rationalities provides the basis of conflicts in the enterprise and that the distinction between formal and substantive rationality is paramount to understand accounting practices. For instance, it is not surprising that rational accounting practices in a traditional society (such as the Ghanaian) may take a substantive form which preserves the interests of the family, tribe and clan (Uddin and Choudhury, 2008; Jayasinghe et al., 2020), or that the institutions of community (e.g. chieftaincy), market and state are intertwined in traditional societies (Dyball et al., 2006).

The foregoing Weberian insights are especially pertinent to our study. As we shall explore, in Ghanaian society, several key elements of traditionalism, including a pure native tenure system of inheritance, chieftaincy, control and authority along age lines, familial domination, and communality, appear to shape formal calculative practices and the organisation of economic resources, particularly, in indigenous organisations (see e.g. Bukari, 2016; Grier, 1979). Thus, Ghanaian society is likely to give rise to a substantive rationality of compliance which includes organisational practices that result from the dictates of traditional values and interests such as trust. Weber's notions of rationality and traditionalism $(1948,1958,1961,1968)$ therefore have much to offer studies into calculative practices and the organisation of economic resources, such as in the Ghanaian indigenous owned and managed organisation investigated in this study.

\section{Research Methods}

The research adopted a case study approach (Yin, 2003) for the data collection. Our research setting was a large, quasi-formal indigenous manufacturing company, which we call TimberCo Ghana, situated in the "Brong Ahafo" region of Ghana. This company characterises the typical indigenous organisational culture in Ghana, articulating both technical-rational calculative measures of organising and decision-making, i.e. management accounting technologies, and 
traditional ideologies and social practices. Data for the study were largely collected through the use of semi-structured interviews conducted both onsite and off-site (see Appendix 1), supplemented by informal conversations and documentary analysis to give a better insight into the interview data (see Appendix 2 for the documents reviewed). Semi-structured interviews enabled the generation of an in-depth understanding of how the Ghanaian traditional culture and social practices have influenced both the functioning of the indigenous company and the use of calculative measures, the result of which has been the domination of substantive rationality in the organisation and decision-making process. The application of other methods such as surveys would have prevented such in-depth understanding of traditionalism and the use of calculative measures in indigenous companies. A semi-structured interview guide was designed by largely focussing on questions which were dictated by the research themes identified through the objectives of this study and the associated theoretical scope based on a Weberian framework of traditionalism and rationality (Weber, 1948, 1958, 1961). The interview questions covered topics such as: organising and decision-making processes of the company; perceptions about the managerial characteristics of the managing director (owner); family issues; culture; budgeting; perceptions about the use of accounting; and future projections.

Access to the company premises to conduct interviews was facilitated by community leaders who were highly respected by the owner of the company. On-site interviews were conducted at the company's premises and off-site interviews were facilitated via Skype and telephone. The off-site interviews not only supplemented the findings of those conducted on-site, but also helped clarify inconclusive interview data and address any follow up issues. In total, 56 interviews were conducted, and informants included departmental heads, general employees, community members, ex-employees, trade union members and representatives of the Ministry of Lands and Natural Resources and the Faculty of Forest Resources Technology (see Appendix 1). The general employees interviewed had worked in the company for more than five years and had extensive knowledge and experience of the day-to-day working practices. The respondents were guaranteed confidentiality and anonymity. The interviews lasted between fifty minutes and one and half hours; they were tape recorded and subsequently transcribed.

As discussed in the previous section, Weber's three layers of analysis (the institutional and structural conditions - external layer; the historical context - external layer; and the organisational context - internal layer), informed the analysis. Data coding followed Miles and Huberman's (2002) three-step data analysis method: data reduction, data presentation and conclusion drawing. Accordingly, in order to reduce the interview data, we facilitated a process of data selection, simplification and transformation from the field-notes. Various organisational practices, such as managerial hierarchisation, production processes, budgetary controls and labour controls, were used to generate the "initial codes". This primary coding was followed by the stage of examining the data for: (i) Weberian notions of traditionalism and (ii) two distinctive forms of rationalities, technical and substantive; and (iii) calculative measures embedded in each of the above-mentioned organisational practices. The later stages of analysis constructed summary narratives of the three layers of Weberian analysis, noting how technical rationality and traditionalism co-exist, subsume and form new substantive rational (Weber, 1948, 1958, 1968) calculative measures of organising and decision-making in the researched organisation. In reporting the findings, we first present the features of the case study company and its associated traditional foundations, and elaborate the notion of the quasi-formal organisation. Secondly, we examine the external layers of traditionalism and rationality which 
impact organising and decision-making within the researched company. Finally, we present and discuss the internal layer of analysis.

\section{The quasi-formal organisation: TimberCo Ghana}

TimberCo was established in 1997 and had a workforce of over 1500 at the outset of the field interviews. It is registered with the Registrar General's Department (RGD) under the Ministry of Justice and Attorney General. TimberCo is also an 'A' registered exporter of timber products to West African, European Union and North American markets. The company is registered with the Ghana Revenue Authority (GRA) to ensure adherence to tax obligations. As such, TimberCo is required to comply with value added tax (VAT) obligations. TimberCo is also obligated to ensure that its employees pay tax on a "pay as you earn" (PAYE) basis. Having fulfilled all these requirements, the legal standing of TimberCo is emblematic of a formal technical-rational (Weber, 1958, 1961) organisational structure.

\section{[Insert Figure 1 about here]}

However, in practice, as shown in Figures 1 and 2, the company demonstrates two organisational structures. The first (Figure 1) is the formal technical-rational organisational structure (largely non-functional, top to bottom), which highlights the chain of command from the managing director (owner) to the general employees. This is what is formally demonstrated on the company's information board and is similar to what would normally be included in the company registration documents formally submitted to Registrar General's Department (RGD). The second (Figure 2) is the practical (actual) organisational structure which has two distinctive chains of command: an owner-manager-informed chain of command and the department heads-informed chain of command. The owner-manager-informed chain of command is what largely occurs in the day-to-day organisation of the production process.

\section{[Insert Figure 2 about here]}

In the formal organisational hierarchy, supposedly, the direct chain of command is initiated by the managers and passes on to the general workers via the department heads. However, in practice what we call the owner-manager-informed chain of command predominates. Under this, there are direct engagements or interactions between the managing director (owner) and the general employees as well as the managing director (owner) and the department heads. Meanwhile, the engagement between department heads and their supposedly subordinate general employees is limited. For instance, the following observation was shared by managerial interviewees:

"This is typically an indigenous-owned company and the management style is sort of mixed. The managing director is involved in almost every activity that takes place. He can go to the bush (forest); he comes to the floor of the factory. Though he seeks technical advice from technicians, his views are final".

Similarly, a supervisor shed light on the internal managing director (MD)-worker relationships: "Workers can go straight to the MD without passing through anyone [i.e. department heads] and vice-versa. When the MD is not here, they [employees] will come and see either the accountant or the production manager. The MD will also not ask us [department head], and will go to the workers to engage them." 
This bypassing of the formal hierarchical structure occurs because in many ways the owner does not trust his fellow managerial staff. Instead, he uses some culturally shaped substantive rational (Weber, 1948, 1958, 1968; Uddin, 2009) mechanisms driven by the Ghanaian "pure native tenure system of inheritance" to construct an alternative form of hierarchisation to manage his general employees and managers. As will be subsequently discussed (sections 6 and 7), examples include: the owner's use of his immediate family members (e.g. brother) to control labour in his absence; the employment and use of people from his own village to gather important internal information; and inviting community leaders (elderly clansmen) to advise (and hence) control the labour force. These external influences are included in Figure 2.

As per field observations, the activities of the company are then, at least in part, organised and controlled under forms of hierarchisation based on the substantive rational (Weber, 1948, 1958, 1961) measures of the traditional inheritance system that exist within the Ghanaian sociocultural contexts. The form of substantive rational hierarchisation that exists within traditional practices in Ghana is on the whole neither formal nor formalised. As such, the current 'written' knowledge of these traditions have resulted from oral recall and transmission of preserved textual and cultural knowledge through vocal utterances. With reference to TimberCo, our study reveals that the 'traditional inheritance system' peculiar to matriliny (as discussed in section 6.2), alongside the 'hierarchisation', creates some inter-connection between the provenance of the company and its calculative measures and control mechanisms. All this results in TimberCo operating as a quasi-formal organisation.

\section{The External Layers: the institutional, structural, cultural and historical contexts}

In this section we analyse the institutional and structural context (external layer 1) and specific features of traditional culture, history and society (external layer 2) in relation to the timber industry of Ghana.

\subsection{Rational institutional and structural context of Ghanaian timber industry}

The timber industry, which operates under the ambit of the Ministry of Lands and Natural Resources, is the fourth largest foreign exchange earner in Ghana after minerals, cocoa and oil exports (Bank of Ghana, 2004; Ministry of Lands and Natural Resources, 2012). The industry comprises primary, secondary and tertiary activities (see Table 1 for the actual activities classified under each activity area). According to Ghana's Forestry Commission (2013), there are 328 timber companies with valid timber holdings. These are the companies with concessions and timber utilisation contracts (TUCs). Additionally, there are more than 200 furniture and wood-working enterprises operating throughout the country. The industry's distinctiveness is represented in its employment creation proportion, which surpasses other natural resources. It is estimated that about two million people directly earn their livelihoods from the timber industry (Gyimah and Dadebo, 2010; Bank of Ghana, 2004).

\section{[Insert Table 1 about here]}

The performance of the industry has been mixed, but in the past years, both the volume and value have registered declines. For instance, timber-related products accounted for about $10 \%$ of exports between 1990 and 2000, but there has been a considerable decline from $8.1 \%$ in 2005 to only $1.8 \%$ in 2011 (Lands and Natural Resources Ministry, 2012). Such a decline is 
perhaps consistent with a reduction in the area of loggable forest which stood at approximately 1.6 million hectares in 2013 (Young, 2017).

Initiatives made by the government over the last few years to control the depletion of the traditional hardwood species by prohibiting the extraction of several types of unprocessed and raw logs have also adversely affected the profitability of the timber industry (Lands and Natural Resources Ministry, 2012). The industry has also been hard hit by the structural adjustment programmes (SAP) adopted by the government, in compliance with the loan conditionalities of the World Bank and the IMF. The SAP has resulted in the promotion of several rational capitalist mechanisms in the Ghanaian private sector, including the removal of subsidies and price controls, the elimination of trade barriers, the promotion of market competition and freedom of movement of labour (Arthur, 2006; Tsamenyi, et al., 2010). As a result, private enterprises, including TimberCo, have been left to their fate, with the intent of allowing external competitive market forces to dictate the local market.

Historically, legislation underlying timber extraction was enacted in 1906 to control the commercial felling of trees, subsequently augmented by the creation of the Forestry Department in 1908. This led to the demarcation and reservation of the forest estate which was largely completed in 1939, and a Forest Policy was adopted in 1948 (Adjei, 1994). The government's total control of Ghana's timber allocation was central to post-independence reforms, which also resulted in the re-ordering of the institutional structures and the power dynamics of the country. Timber rights were vested in the president and the state on behalf of the stools (local chiefs) by virtue of the Concessions Act of 1962. For this reason, felling rights on and off forest reserves were granted under the sole prerogative of state-appointed authorities (Lund et al., 2012). This provision was altered however, after sections 1 and 4 of the Timber Resources Management Act of 1998 (Act 547) (amended in 2002 by Act 617) were put in action. Based on this Act, the felling of trees is recognised under the following permit categories: Timber Utilisation Contract (TUC); Salvage Permit (SP); Timber Utilisation Permit (TUP), Special Permits, Timber Leases and Certificate of Purchase.

A TUC is a written contract signed by the Minister for Lands and Natural Resources and ratified by Parliament, granting a timber harvesting right acquired upon "competitive bidding" by Ghana Forestry Commission (GFC). Since 2003 the process of issuing TUCs to timber firms has been undertaken in the presence of the public, press, the industry and members of parliament (Parliamentary Select Committee on Lands and Forestry). The intent is to dispel the familiar accusations of collusion, nepotism, cronyism and political favouritism in the allocation of timber resources. TUCs typically have a duration of up to 40 years and cover a maximum area of 12,500 ha. (Young, 2017). The SP is an administrative permit signed by the Forestry Commission to salvage trees from an area undergoing development. To be considered for this, the permit needs to be accompanied by the application and an inspection report from the Forest Service Division, while the TUP is a small-scale permit to harvest a defined number of trees for social or community purposes signed by the Forestry Commission. Timber from these permits cannot be sold or exported.

However, the actual practice of bidding for TUCs remains discretionary, subject to secrecy, political party affiliation, self-seeking and cronyism, with widespread illegal and criminalised chainsaw lumber operations (Hansen and Lund, 2011; Hansen et al., 2012; Lund et al., 2012). Furthermore, the government's direct control of private timber companies goes beyond concessionary procedures. Specifically, access to foreign markets for timber products is subject to the sole dictates of the government. The GFC promotes timber trade by helping timber 
companies gain access to foreign markets and also creates investment opportunities in the timber industry. As a policy requirement, the GFC has been entrusted with ensuring legalised lumbering access to markets and sustainability through forest re-plantation. The GFC is also responsible for ensuring that timber companies comply with the European Union's Forest Law Enforcement, Governance and Trade and Voluntary Partnership Agreement (FLEGT-VPA). The EU's FLEGT-VPA is part of a sub-global initiative or action, as well as climate mitigating policy, of reducing emissions from deforestation, forest degradation as well as serving as a mechanism to combat trade in illegal logging (Ochieng et al., 2013). Compliance with this agreement facilitates the smooth exporting of timber products to the European market.

\subsection{Historically evolved features of Ghanaian society and culture}

This section discusses aspects of the historically established (traditional) culture and social practices in Ghana which particularly impact on TimberCo. We highlight the lineage trail of ownership in relation to the case study company and the power of "chiefs".

\subsubsection{Lineage trail of ownership}

In Ghana, in common with much of sub-Saharan Africa, land is mainly owned communally along ethno-tribal and family lines, with designated traditional authorities responsible for its management in their capacity as trustees (Kasanga and Kotey, 2001; Boni, 2005; Aryeetey et al., 2007; Boni, 2013; Yeboah and Shaw, 2013). It is largely the responsibility of chiefs to sell land under leasehold agreements to interested parties. Land rights and tenure are enshrined in a complex legal and customary environment of Ghana (Kasanga, 1998). The customary owners (stools, clans, families and tendamba) with allodial title own about $78 \%$ of the total land area in Ghana, with varying tenure and management systems (Kasanga and Kotey, 2001; Ministry of Land and Natural Resources, 2012).

TimberCo Ghana is no exception to the influence of Ghanaian traditional practices. The company's history and ownership are rooted in the traditional matrilineal system of inheritance that is associated with the 'Akan' in Ghana. The distinctive features of such a system are that inheritance and family are along the lines of the mother. That is, a man is strongly related to his mother's brother (wofa) but only weakly related to his father's brother ${ }^{1}$. As a result, in inheritance, a man's nephew (sister's son) (wofase) will have priority over his own son. Therefore, uncle-nephew relationships assume a dominant position (La Ferrara and Milazzo, 2017). Although legislation (the intestate succession law) was promulgated in Ghana in 1985 to alter this traditional pattern of inheritance, its continuation is witnessed in recent inheritance litigations among some families. In effect, the Akan inheritance and succession system stipulates that property and status are transferred from the mother's brother to sister's son. Nonetheless, it is a more complex principle than the usual examples given in anthropological explanation. For instance, in some instances, when a man's brothers are available, a consideration of generational seniority stipulates that the line of brothers must be exhausted before the right of succession passes down to the next generation (i.e., sister's son).

This lineage trail is manifested in TimberCo Ghana's organising of production. For instance, the current peri-urban location of the company is a result of the lineage trail linked to ownership. Specifically, an uncle-nephew relationship preceded the ushering of the owner (nephew) into the timber business. The company's accountant narrated that: "when the owner's

\footnotetext{
${ }^{1}$ http://www.twi.bb/akan-matrilineal.php
} 
uncle demised, he took over to revamp the company". Its original location was in the owner's native village, about 15 miles from the current location. The land on which TimberCo was initially situated (before being handed over to the nephew) was family land, which was managed and controlled by the uncle. After being given the mantle of control, the current owner (nephew) changed the name of the company and this led to conflict with extended family members. The conflict stemmed from the view that the new name connotes personalisation of the company, which in some sense contradicts the cultural lineage characterisation of inheritance. In an attempt to resolve this impasse over the years, the owner acquired the present site for the company as his 'own'.

Therefore, the traditional inheritance system still plays a role in the organising and decisionmaking of the company, notably the location of the case company. Thus, the existence of such traditional narratives corroborates the view that organising economic resources in developing countries is not underscored by a mere objective process, but rather norms, cultures and histories that define, describe, analyse and contextualise the process.

\subsubsection{The royalty payment to "Chiefs"}

The incorporation of Ghana's producers into the expanding worldwide capitalist system did not result in the immediate capitalist transformation as assumed by Frank (1969), nor in the eventual transformation predicted by Rey (1971) (see e.g. Grier, 1981). This is a recognition of the inevitable aspects of local factors which have the propensity to influence the organising and the calculative functioning of organisations in Ghana. One of the most obvious of these inevitable local factors are the chiefs, a class of persons who exercise considerable authority (Douglas, 1999) and whose rights may (or may not) be considered as arbitrary, irregular, domineering and predatory in the enjoyment of their prerogatives. For example, the chiefs may interfere with the operations or the organising and the calculative functioning of companies within their jurisdictions in Ghana. The essence of this is in the cultural significance of chieftaincy: it is not merely that certain individuals are extremely powerful, but also that the power associated with these cultural practices is unquestioned.

This aspect of traditionalism significantly impacts the calculative functioning and the organising of timber product manufacturing in our case study company. Organising timber product manufacture is partly shaped by chiefs' impetuses in the forms of patronage of social and production relations (Alawattage, 2011) that exist between the chiefs (as land owners and custodians) and the timber companies (as concession owners). The company's raw material cost composition partly accounts for royalty payments to chiefs, legitimising concessionary practices. Additionally, raw material costs include further miscellaneous payments to chiefs in instances where rituals (such as libation) are performed before logging activities. Table 2 shows timber business royalty payments linked to the chieftaincy institution in Ghana. The table's line items are an indication of the contribution to the chieftaincy institution from the timber industry. This highlights the significant economic influence and authority of the chieftaincy institution on timber production in Ghana.

\section{[Insert Table 2 about here]}

Timber concession areas form part of the lands owned (communally) by families and managed on their behalf by family heads (elders). The chief, usually the head of one of the constituent lineages, along with the other heads (elders), make up the council that manages the village lands. The chief, in council, acts as trustee over allocated and unallocated land. In some 
communities, unallocated land cannot be cleared before the council grants its permission. Lineage membership entitles a person to clear and cultivate as much land as his resources allow. Due to the conflict between the land ownership and concession ownership (logging rights), timber companies, seeking to access their concessions, are occasionally faced with blockades from families. For instance, elders of communities and lineage heads may interrupt the logging and carriage process, due to their claim of ownership to concession lands. Such interruptions incur costs which, in the case company, is accounted for as part of the raw materials acquisition cost.

As just described, the distinctive way of organising raw material resources for production is a result of the conflict which emanates from the need for companies to ensure lineage production relations. A TUC grants timber companies the legal right to own an allocated forested area for logging. However, conflict arises whereby the land occupying the same forested area is owned by families, lineages or chiefs. Therefore, although having TUCs from the government was a precondition to accessing logs from concessions, the accounts from interviewees highlight that the procurement of timber logs is not only charged by relations of and with the central government, but by the relations of and with the chiefs and the community. For example, in instances where landowners initiate farming activities during the concession period, trees may be cleared by farmers which limits the projected raw materials acquisition. Furthermore, farmers may resist transporting logs across their land, as stated by a Production Manager:

"But that forest may be somebody's farm and you have to pull the logs through. The guy gets annoyed and the next time your way will be blocked."

Communally-informed initiatives therefore lie at the very core of traditional timber production in Ghana. Part of the communal manifestations of African production relations or social arrangements is underlined by a life in which the endowments are regarded as assets of the community. As such, popular decisions are the ones geared towards community or individual "proportionate" share of such assets. Moreover, it is within the consciousness of Ghanaians that the capacity of individuals and communities to organise or disorganise resistance is tenable - an example of which is the resistance in the form of the timber company having to meet or conform to further demands by chiefs, individuals or communities before being allowed to extract timber logs. The sense of conflict and resistance is linked to the post-independence, constitutional mandate of entrusting the "ownership", management or the administration of forests resources, among other landed properties, to the state. This agitated the chiefs, communities and some families who in turn have used their status as a significant indigenous political order to circumvent most of the policies of the central government to their benefit. Instances of chiefs using their authority to influence voting patterns and numerous litigations by families and chiefs to reclaim ownership of landed properties vested in the central government are prevalent in Ghana.

Further tensions between the state and cultural practices can be observed in the sustainability of the timber industry. This has historically been hampered by concession management and control practices which, under governmental bodies, have undermined the indigenous cultural traditions of Ghana where used timber concessions are left to replenish themselves naturally over a 25 year period. However, it being the sole prerogative of the government of Ghana under the constitution to grant natural resource rights, the replenishment and forage cycle for used timber concessions has changed. The following lines of testimony from a supervisor express the "forage cycle" associated with concession usage replenishment practices of the timber industry: 
"We are... using the 40-year forage cycle. It used to be 25 years and was changed to 40 years. ... You will not be permitted to come to the same place to do any harvest until 40 years. The issue is that if you go in for harvesting, we have what we called natural shock, so we want the remaining to species to recover from this shock through natural process.

Part of the above regulation and policy was enacted by the colonial administration in Ghana to control the felling of commercial trees. Accordingly, these two different "forage cycles" have been used for planning and monitoring strategies for the timber industry.

To summarise our analysis of the external layers (Colignon and Covaleski, 1991; Weber 1958), the timber manufacturing industry is rooted in a multidimensional set of social processes that resists being confined to a single thematic framework. The laws and regulations associated with the timber industry reach deeply into historical, socio-economic, political and cultural developments and transformations that have taken place in Ghana over centuries. Organising timber product manufacture intertwines with customary (traditional) demands and with the institutional and structural context. Customary (traditional) factors pervade the organisation and the calculative practices of the case company and yet formal rationality is necessary to ensure means-end rational calculation (Kalberg, 1980), compliance with formal rules, laws and regulations, to allow business operations such as market access, sales and continuation of TUCs usage. We now turn to the internal layer, where we observe Weber's polymorphous concept of rationality and the formal and substantive concepts of rationality (Kalberg, 1980) provide explanations for the organising and the calculative functioning of TimberCo.

\section{Organisational context and calculative measures of organising and decision-making}

Based on field work evidence, this section analyses the organisational context (internal layer) and calculative measures of organising and decision-making in the TimberCo Ghana. We discuss, in turn: (i) raw materials acquisition; (ii) manufacture of timber products; (iii) labour control and native forms of resistance; and (iv) budgeting and budgetary control practice.

\subsection{Raw materials acquisition}

The actual manufacture of product begins with obtaining TUCs or concessions. The attainment of TUCs is underscored by a competitive system of public bidding for rights to harvest timber in an allocated area, on the basis of an annual timber rights fee for a term of forty years. However, the public bidding process for TUCs is noted to be fraught with corruption, politics and secrecy. Indeed, there have been cases of people with TUCs who did not have the prerequisite for bidding for timber concessions. TimberCo harvests timber from its legally allocated concession(s) and transports them to the company's premises. However, this process may be curtailed if the companies conform to the dictates of chiefs and communal hierarchical relations - an indication that the authority of traditional chiefs in terms of logging and concessionary practices, has not diminished and this illustrates the presence of substantive rational (Weber, 1958, 1961) calculative measures for the TimberCo raw material acquisition and control. This is corroborated by the following remarks from a Production Manager associated with the timber industry:

"Earlier, we were required to acquire concession to be involved in timber-related businesses and contracts. We now need to apply for the Timber Utilisation Contract at 
the Forestry Commission of the Government of Ghana. First, we need to make an application and the commission will assess our application based on certain factors: for instance, the equipment we are using to do actual harvesting. We also need to pay stumpage fees during the contractual agreement. Previously, the stumpage fees, also called royalties, used to be 60/40, i.e. $60 \%$ for the forestry commission and $40 \%$ for the local authority, i.e. the chiefs, stool lands. The chiefs were not satisfied, and a new proportion has been agreed. Now the proportion is 40/60; the government takes $40 \%$ and the rest (60\%) is allocated to the chiefs, stool lands."

Similarly, there are community influences on the logging activities of the timber company, as observed by one of the Production Managers:

"Before you enter an area and take the timber you have to meet the local people, the assembly man, etc. and discuss... Even though the government has given you the permit to enter that area, you cannot do the felling and extraction without negotiations with the local people. The locals may say they want to build a school and you may negotiate with them by offering, for instance, 100 bags of cement and other items, such as roofing sheets. If they agree, then you would be allowed to enter the forest. [The] permit alone is therefore not enough."

What is inferred from this is the existence of traditionalism with regards to calculative measures linked to acquisitions of raw materials. The timber companies, including TimberCo, to some extent comply with the dictates of the concessions under the "landed" control measures of the respective chiefs. The subsumption and the sustenance of Ghana's chieftaincy in the administration of forests, which is constitutionally reserved solely for the presidency, is evident. This also attests to the chieftancy's historical superior legacy and its cultural strength in working hand in hand and in conflict with, an alien rational capitalist central governance and control system. For instance, a striking feature of the influences of chiefs during the colonial rule on the Gold Coast (which became Ghana after independence on $6^{\text {th }}$ March 1957) emerged as the fact that three hundred "Native Courts" heard 83000 cases at law in the single year 19501951 (Rathbone, 2001). The substantive rational (Weber, 1948, 1958, 1961) community relations thus play a part in logging and concessionary activities.

Besides exploiting the concessions under its control, TimberCo can further acquire additional raw material (timber) in two ways. First, the company stands ready to purchase timber logs from other TUC holders who can transport their harvested logs to TimberCo's premises (preferred option). Second, with permission from other concession owners, TimberCo can fell and transport their timber logs to its premises. These two types of raw material acquisition calculative measures are replete with varied forms of irregularities e.g., corruption and thievery. Nonetheless, these non-concessionary purchases and logging practices lead to a considerable reduction in TimberCo's raw material costs as it eliminates the need to directly engage with local chiefs. The statement below from the Head of Logs depicts how the company has relied on non-concessionary purchases and logging practices while sourcing raw materials:

"We also buy logs at our premises. There are people with concessions but without the facilities to process the logs further. What they do is, they do their own felling, bring the logs to our premises and we buy the logs from them."

TimberCo's decision to engage in non-concessionary purchases and logging practices stemmed from the significant raw material costs associated with operating its own concessions. For instance, besides the elimination of the need to make payments to chiefs, TimberCo can also 
reduce the cost associated with paying tips to timber truck drivers to meet delivery schedules. Accounts from interviewees suggest that, in organising raw materials, timber truck drivers intentionally delay the carriage process by blaming blockades, bad roads and the rainy season, to demand extra money from company management. For example, the rainy season mostly destroys large parts of the untarred forested road networks. However, a respondent from the log department noted that, whenever timber truck drivers are given tips, they are in the position to facilitate a 'smooth' carriage of timber logs to the company premises. Therefore, to circumvent some of these concessionary raw materials acquisition costs, timber companies are likely to be in tune with substantive rational non-concessionary forms of acquiring raw materials.

The term of forty years for concession practice without proper afforestation measures has resulted in diminishing forest cover in Ghana. As such, timber companies face a decline in logs (raw materials) supply. Timber companies, therefore, rely on additional veneer purchases and supplies from the Ivory Coast, Ghana's neighbouring country. By sourcing veneer from the Ivory Coast, companies grapple with substantial increases in raw material costs, such as translation loss (currency exchange) due to a weak local currency, transportation costs, border delays and charges, and bribes (to reduce delays at border checkpoints).

\subsection{Manufacture of timber products}

The case company specialises in plywood production. The entire manufacturing process takes place at the company's premises. First, the number of transported logs to the company premises are recorded at the security section (i.e. the main entrance). From here, the logs are transferred to the logs section for further counting and cubic metre measurements. The cubic metre measurements are used to predict the number of finished plywood sheets that could be manufactured from the measured logs. Although cubic metre measurements are used as a predictive value, their relevance relies on additional pieces of information before they can be regarded as a confirmatory value. This is in line with calculating what may cause adverse variances in budgeted and actual finished products. The timber company largely attributes such shortfalls to theft, with other reasons for shortfall being intentional miscalculations, cubic metre measurement and sectional inefficiencies and log deficiencies. After cubic metre measurements, the logs are sent to the production department where the initial process is to cut the logs into preferred measurements for de-backing. Production work is semi-automated, with 30 percent automation and 70 percent manual. Some of the production work linked to manual handling was de-backing of logs for further automated processing. As observed by one of the Production Managers:

"Labour is cheap when you consider the fact that many people are willing to work with the tools known to them... The man is used to an axe, so when you tell him to use an axe, he doesn't feel anything. That is normal to him."

In this process, workers use locally manufactured tools such as the axe and the cutlass. With automated de-backing, the logs are placed on a de-backer (machine) which de-backs the logs efficiently along its long blade in a rotary and even manner. However, it was evident that manual de-backing could result in considerable wastage of veneer due to the use of inappropriate local implements. Additional production processes include using the de-backer to cut out veneer, placing the veneer into preferred shapes and then forwarding these to the pressing machine. Other follow-up processes include cutting the pressed veneer into preferred measurements, drying and counting the finished products for distribution. 
TimberCo's production process highlights substantive rational (Weber, 1948, 1958, 1961) forms of practices, concealed within the Ghanaian traditional social and production relations, which may in part facilitate or hinder (Alawattage, 2011) the possibility for rational organising and decision-making practices. Timber production is measured and controlled by departmental heads who are linked to the production line. The production manager supervises the activities of departmental heads, whilst the managing director (owner) oversees the activities of all employees, epitomising Western-centric organisational control/managerial hierarchy.

However, close examination of these organisational formations and control systems reveals novel traditional substantive rational production relations that interpenetrate the formal technical-rational (Weber, 1948, 1958, 1961) form of production practices. For instance, the position of departmental heads was based on seniority and generally reserved for elders. Such a gerontocratic idea of delegating authority to control organisational affairs is deeply ingrained in African societies (Douglas, 1999) as we discuss further in Section 7.3.

Invariably, the managing director (owner) micro-manages all the departments within the company. For instance, even when the managing director (owner) is away from the company, he is to be reached for his final say during decision-making. It emerged during our interviews that there exists no trust between the owner and those who have been delegated to control all the respective departments. For example, a Head of Accounts/Finance Department remarked:

"What I see is that the owner does not trust anyone when it comes to the money aspect. I cannot say what exactly it is, but my mind tells me that it could be that someone might have done something to him. Maybe he entrusted the financial aspect to the person and something might have happened. That is why he himself wants to do it".

Those the owner appoints to lead the departments were considered the lesser of the "evils". The owner's testimony revealed that his ingrained managerial stance characterised by a lack of trust in his department heads is as a result of the advice from elders. Evidence from the production process supports the managing director's stance. For instance, some production employees misuse calculative measures through false cubic metre measurement and undercounting and subsequently connive with buyers to withhold the difference between the undercounted finished products and the actual finished products. Su Leen Tan and Woodward (2005) observed that trust is important in a variety of management accounting and hence, control applications. In the context of the researched company, control applications and calculative measures are in part underlined by lack of trust in the reliability of the appointed sectional managers or employees.

The lack of trust is further evident in that when the owner was away a member of the owner's family could sometimes come in and oversee the affairs of the company, as described by a supervisor in the accounts/finance department:

"The owner's brother comes here to see to the affairs of the company when the MD is away”.

The owner's brother is in a significant position in inheritance succession and this action is backed by the substantive rational (Weber, 1948, 1958, 1961) "pure native tenure system of inheritance" that is rooted in the provenance of the company. As such, this particular family member wields some level of power in terms of succession in inheritance. Therefore, it is not 
any mere member of the family who could walk into the company and control its affairs when the managing director (owner) is away.

\subsection{Labour control and native forms of resistance}

Culturally informed substantive rational (Weber, 1948, 1958, 1961) labour control in the company was evident in both the recruitment process and power dynamics in the workplace. The company's stratified recruitment procedures and practices were in themselves forms of controlling the labour and its associated forms of resistance. This was evident in the manner in which the workers were recruited to perform the manufacturing work. For instance, some of the non-managerial employees who were interviewed had no formal contractual employment agreement and casual workers were noted to be in a similar situation. A formal contractual signed agreement was largely limited to those in management positions (i.e. heads and assistants of sections).

The company's employment measures and procedures take the following forms. Full-time permanent workers are first employed as casual workers after which recommendation to permanent employment is at the discretion of department heads. It was evident that no such recommendations were ever rejected by management. However, most of the workers who are permanently employed based on recommendations from department heads have no written contractual agreements with the company. Timber work recruitment was through established social relations based on department heads' assessment of the casual workers' past performance. In this regard, for most of the workers, becoming a permanent employee of the company was not in consonance with formalised recruitment measures and procedures linked to formal rational recruitment relations. Nonetheless, after recruitment, in the absence of written contractual agreements, their employment was, in part, formalised and acknowledged through the award of different wage scales. The other implication of this is that the power to control labour is vested in department heads. For instance, department heads were noted to have the power to hire or fire employees based on their substantive rational (Weber, 1948, $1958,1961)$ measures and judgments of the employees' performance. This shows that the organisation's recruitment tradition is partly in line with an agency perspective (Eldenburg and Krishnan, 2007) on the nature of employment contracts - which is to maximise organisational performance out of the situational problems.

Figure 2 highlights the internal structure of the company for organising the manufacturing of plywood products. There are different departmental positions within the company. These positions constitute the dynamics of power relations and their associated magnitudes. In other words, the level of the hierarchy of authority or influence is represented by the following. The occupied space of each circled position represents the proximity of the department heads to the Managing Director (MD). The frequency of interaction between the MD and the department heads is represented by the dotted (intermittent interaction) and straight lines (frequent and/or continuous interaction).

The selection of who becomes a department head is partly based on experience, age (i.e. the elderly) and propinquity (family connection, people of similar lineages from the owner's village/hometown). It is evident from this study that the communal practices of delegating the hierarchy of responsibilities along the lines of age and seniority similarly underline the organising and calculative practices of the researched company. Elder status was a prerequisite in selecting someone to head or supervise departmental activities. In assessing the impact of 
elders on the ways timber production is organised, it was noted that employees are unable to subvert the power and authority enshrined in the gerontocratic consciousness of the people. As such, due to respect for age (elders) in Ghanaian socio-cultural relations, people conform to the orders from elders. The following testimony of a general employee serves as an example:

"We do not have problems with our supervisors. We do what they instruct us to do. When we sometimes disagree with what they say, we consider the fact that they are elderly and experienced. Therefore, we do what they say."

Moreover, as identified by Adegbindin (2011), "gerontocracy" (the traditional and social significance of a person's age) is the substantive rational (Weber, 1948, 1958, 1961), for the traditional African respect for the authority of elderly persons, through their experience, wisdom authority, leadership and knowledge of community affairs. The premium people place on the elderly in Africa, as seen among the employees in the researched company, is such that elderly clansmen wield the authority to curtail resistance. Furthermore, we found that the managing director (owner) relies on community leaders (elders) to meet with workers to advise them on the need to have a positive work ethic. One ex-employee, for example, shared his experience:

"The MD even invited [an external community elder] to the company to have a meeting with us. [The Elder] advised us on the need to see the work as ours and we were asked to work harder to sustain the organisation's performance."

Although the effect of this intervention on work output was not directly measured, it was a strong indication of the reliance on substantive rational (Weber, 1948, 1958, 1961) traditional social structures to condition labour, in creating economic value and wealth in Ghanaian timber companies.

Therefore, the implication of age in Ghanaian social relations is that there is a practical implication of age as a calculative measure in the control of labour in timber manufacturing. Specifically, elders are used to organise product manufacture in a way that avoids resistance, thereby ensuring the smooth control of labour. The sustenance of labour control is further backed by the company's internal position of allowing major departmental heads to recruit or sack employees. Thus, resistance to orders is curtailed as workers are deterred by the knowledge that they may be arbitrarily sacked by their department heads.

A final means of controlling labour was in employing people the manager knows. Many of the company's workforce come from the owner's village and some of them hold head of department positions, underlying the substantive rational (Weber, 1948, 1958, 1961) 'native tenure system'. The following remark by a Managerial Respondent from the production department is underlined by the native proportionate share of the labour force:

"Here, a large proportion of the workers comes from the owner's hometown. Employment is through casual process. When someone is finally employed, we open a "file" for the person. However, the file does not say how much a worker is to be paid at the end of the month. But the skilled workers have their contract terms stated, including their salary for the year".

He also relies on his townspeople to fill in temporary labour shortfalls emanating from absenteeism. 


\subsection{Budgeting and budgetary control practice}

We turn now to budgeting and budgetary control practices, illustrating the intertwining of a substantive rational perspective with financial control. The company employs a form of partial-participatory budgeting. The budgeting process starts with the owner requiring periodic departmental reports from the heads of respective departments. These reports include the calculative measures such as log requisition records for the period, sales records, and units manufactured. After these reports are collected, the owner then discusses the reports with the heads of the key departments of the company: the accounts/sales office, the logs department, the production and marketing department and the security department. The discussion largely centres on the attainment and non-attainment of performance targets and associated reasons. The owner schedules separate meetings with each department head to have such discussions. This mode of engagement with department heads is illustrated by Figure 2, which typifies the direct engagement or interaction between the managing director (owner) and the heads of departments. During such meetings, the owner generally solicits views from the respective department heads in relation to performance measurement records. However, per respondents' testimonies, these views are generally not acted upon. Thus, the judgments on the employee performances are based on the substantive rational (Weber, 1948, 1958, 1961) measures of the managing director (owner) rather than formal controls.

The managing director plays a major role in controlling the operations of the company. For instance, each day, the managing director (owner) carries out three-hourly physical checks (audits) to calculate and measure departmental conformity to planned activities. Due to mistrust in his employees, he also routinely audits payments and receipts. The following response from the managing director corroborates the above:

"Each payment requires my approval. This allows me to have full details of all payments incurred. I do not delegate accounts keeping to other people; they may write anything and frame a story to veil the truth. What they think all the time is to find ways to steal money. For instance, if I send someone to put fuel into a vehicle, I also ask them to bring the receipt. Even with such strict scrutiny, I will not be surprised if the person partly fills the fuel tank and sells the remainder of the fuel to someone. So, I also need to check the vehicle sometimes".

In order to further ensure that the control mechanisms work, the owner relies on the information provided by his townspeople, community and elders (as seen in Figure 2). Many of the employees hail from the owner's village and this highlights the importance of propinquity for the managing director (owner)'s organising and decision-making. The owner's trust of his townspeople was presumably also related to the esteem in which he was held. As a general employer stated,

"The [MD's townspeople] listen to him. I am not surprised, considering his wealth and influence."

The above is an indication of how trust, communality, family and gerontocracy shape planning and budgetary controls in TimberCo Ghana.

\section{Discussion and conclusions}

Employing Weber's concepts of traditionalism and rationalities (Weber, 1948, 1958, 1961, 1968) and Colignon and Covaleski's (1991) three-layer analysis, we have in this paper demonstrated how the institutional and structural conditions embedded within the historically 
evolved features of the Ghanaian society create substantive rational calculative measures of organising and decision-making practices in a quasi-formal organisation, TimberCo Ghana. That calculative practices play an important role in the functioning of organisations and society is covered extensively in prior work (Miller, 1994; Hopwood, 1983; Hopper et al, 2009; GuvenUslu et al., 2020; Lapsley et al., 2020). Previous accounting studies about calculative practices in developing countries have drawn on three different kinds of organisational settings. While the first strand of studies shows the application of calculative practices within formal structured organisations operating in traditional societies (Uddin, 2009; Uddin and Choudhury, 2008), informal settings such as rural and indigenous communities have become the focus of the second strand of studies (Gallhofer and Chew, 2000; Walker and Llewellyn, 2000; Jayasinghe and Wickramasinghe, 2007; Alawattage et al., 2017; Jayasinghe et al., 2020). The third strand of research pays attention to formalised and bureaucratic public sector entities in which rational calculative measures designed for the private sector, have been imposed at the behest of international organisations and development partners, as part of governance and accountability reforms (Wickramasinghe and Hopper, 2005; Van Helden and Uddin, 2016; Hopper et al., 2017). The failure to enforce the calculative measures as intended, as well as their inability to engender the expected results, is evident in all such studies undertaken in different settings in developing countries.

Rarely, however, have accounting studies investigated how rational calculative measures might operate in quasi-formal organisations, despite these being perhaps the most widespread forms of organisations in developing country contexts in general and in sub-Sahara in particular (Harriss, 1978; Hopper et al., 2009; Guha-Khasnobis et al., 2004). As has been discussed, these organisations blend the formal rational structures and requirements of private management practices with traditional cultures and social practices. The present study of a quasi-formal organisation is therefore a significant addition to our understanding of calculative measures operating in this kind of under-researched setting. The divisional structures of the researched organisation, TimberCo Ghana, attest to the presence of modern corporate apparatuses, but its practical work relations are instead in part organised and controlled under the form(s) of the hierarchisation that characterises Ghanaian socio-traditional contexts, adhering to the pure native tenure systems of inheritance and trust. This form of hierarchisation, which is central to traditional practices and widespread in Ghana, is largely neither formal nor formalised (e.g. Grier, 1981).

Our key empirical contribution is to highlight how the technical legal ramifications and historical features of a developing country dominate the institutional and structural conditions in which formal organisations operate and which provide such organisations with a basis for undertaking rational decision-making. For instance, despite the influence of structural adjustment programmes and free market policies of the World Bank, the European Union and development partners, the researched company, TimberCo Ghana, faces restricted institutional and structural conditions due to the continuity of the legally controlled concessionary practices such as the timber utilisation contracts (TUCs). The historically established features of Ghanaian society, for instance, the pure native tenure system of inheritance, chieftaincy, royalty payments, familial hegemony, gerontocracy and trust, have made the institutional and structural conditions in which the timber industry operates much less relevant. In consequence, all formal rational decision-making and calculative mechanisms function according to substantive rationality (Weber, 1958, 1961, 1968). Within TimberCo Ghana, the local chief's decision was central to the acquisition of raw materials (timber logs) and the control of timber resources. The labour control measures enforced were based on pure native tenure hegemony and underlying traditional power dynamics. Judgments on employee performances were made 
following the community leaders' (elders) recommendations rather than the formal measures. In summary, this evidence illustrates that the traditional cultures and social practices still play an influential role in the dynamics of organisational practices in Ghana, and by implication in other parts of sub-Saharan Africa (Ntiamoa-Baidu 1991; Appiah-Opoku and Hyma 1999; Chenhall, 2003).

The notions of traditionalism and rationality we have employed in the study have enabled us to study the case organisation, TimberCo Ghana, within its historical, economic and political context. Thus, our theoretical contribution is to highlight the interplay between formal and substantive rationalities in traditionalism, where rational regulatory frameworks and practices are not enforceable. Indeed, the importance of a distinction between formal and substantive rationalities which engenders a better understanding of organisational practices is highlighted in prior work (Uddin, 2009; Jayasinghe et al., 2020; Uddin and Choudhury, 2008). We add to existing work by illustrating how the interplay of, and tensions between, formal and substantive rationalities play out in a formal organisation, TimberCo Ghana in our case, which transforms and functions as a quasi-formal organisation. The rational structures for organising and decision-making and calculative measures are features of TimberCo Ghana. However, traditionalism has led to the transformation of these features into a particular form of substantive rationality at the organisational level, thereby preserving and perpetuating the elements of Ghanaian society, such as chieftaincy, royalty payments, familial hegemony, gerontocracy and trust, in day-to-day practice.

Finally, there are important implications for policymaking in traditional societies, which are still very much part of the culture of developing countries. Our case study clearly illustrates the need for Western-led organisational rationalities to adapt to traditional practices to ensure the optimal organisation of production processes, particularly in sub-Saharan Africa. Our findings also contrast with some previous studies of traditional societies. For instance, Hindess and Hirst (1977) discuss the historical trend in which capitalist production rationalities tend to subjugate traditional ones initially through 'merchants' capital, then through 'commodity exports' and finally through 'imperialism' (see also, Hopper et al., 2009). However, our case study leads us to suggest that different traditional practices can work alongside the capitalist or Western production rationalities. Furthermore, Boafo-Arthur (2003) notes that historical challenges in the form of colonial attempts to sidestep Ghana's chieftaincy, and the attempts by the immediate post-independence governments to subjugate and divest chiefs from their economic strength through drastic laws, did not intimidate this traditional institution. Policy makers in sub-Saharan Africa and other developing countries, such as the World Bank, the IMF and the African Development Bank, need to understand this underlying institutional and structural (Weber, 1958, 1961) reality, should they wish to enforce better suited rational development policies for formal organisations operating in the traditional settings of developing countries. Given that each developing country is distinct (Van Helden and Uddin, 2016) and that traditionalism and rationality vary in different settings (Miller, 2001; Hopper et al., 2009), further research on formal organisational practices in other developing countries is warranted. 


\section{References}

Adegbindin, O. (2011), "The problem of gerontocracy in Africa: The Yorùbá perspective as illustrated in the Ifá corpus", Human Affairs, Vol 21 No. 4, pp. 454-469.

Adjei, K. (1994) Forest Laws and Regulations, [Online]. [Assessed 3 November 2013]. Available http://www.fcghana.org/library_info.php?doc=43\&publication:Forest $\% 20 \& \% 20$ Wildlife $\% 20$ Policy\&id $=15$.

Alawattage, C. (2011), "The calculative reproduction of social structures - The field of gem mining in Sri Lanka”, Critical Perspectives on Accounting, Vol. 22 No. 1, pp. 1-19.

Alawattage, C. and Azure, J. (2019), "Behind the World Bank's ringing declarations of "social accountability": Ghana's public financial management reform", Critical Perspectives on Accounting, in press.

Alawattage, C. and Wickramasinghe, D. (2008), “Appearance of accounting in a political hegemony, Critical Perspectives on Accounting, Vol. 19 No. 3, pp. 293-339.

Alawattage, C., Hopper, T. and Wickramasinghe, D. (2007), "Introduction to management accounting in less developed countries", Journal of Accounting \& Organizational Change, Vol. 3 No. 3, pp.183-191.

Alawattage, C., Wickramasinghe, D. and Uddin, S. (2017), "Theorising management accounting practices in less developed countries", in Harris, E. (Ed.), The Routledge Companion to Performance Management and Control, Routledge, London, pp. 285-305.

Anderson, S.W. and Lanen, W.N. (1999), "Economic transition, strategy and the evolution of management accounting practices: the case of India", Accounting, Organizations and Society, Vol. 24 Nos 5-6, pp. 379-412.

Appiah-Opoku, S. and B. Hyma. (1999), "Indigenous institutions and resource management in Ghana” Indigenous Knowledge and Development Monitor, Vol. 7 No. 3, pp. 15-17.

Aronovitch, H. (2012), "Interpreting Weber's ideal-types", Philosophy of the Social Sciences, Vol. 42 No. 3, pp. 356-369.

Arthur, P. (2006) "The State, Private Sector Development, and Ghana's Golden age of Business", African Studies Review, April.

Auyeung, P. and Ivory, P. (2003), "A Weberian model applied to the study of accounting regulation in late Qing China", Accounting, Business \& Financial History, Vol. 13 No. 1, pp. 5-26.

Bakre, O., Lauwo, S. and McCartney, S. (2017), "Western accounting reforms and accountability in wealth redistribution in patronage-based Nigerian society", Accounting, Auditing \& Accountability Journal, Vol. 30 No. 6, pp. 1288-1308.

Bank of Ghana. (2004), Report On The Timber Industry In Ghana, Research Department, Sector Study Series, Vol. 2 No. 1, January.

Boafo-Arthur, K. (2003), Chieftaincy in Ghana: Challenges and Prospects in the 21st

Century, African and Asian Studies, Vol. 2 No. 2, pp. 125-153

Boni, S. (2005), Clearing the Ghanaian Forest: Theories and practices of acquisition, transfer and utilization of farming titles in the Sefwi-Akan area, Institute of Africa Studies, University of Ghana, Legon Accra.

Boone, C. (2013) Property and Political Order in Africa, Land rights and the Structure of Politics, Cambridge University Press, New York.

Boudon, R. (1997), "The present relevance of Max Weber's wertrationalitat (value rationality)", in Koslowski, P. (Ed.), Methodology of the Social Sciences, Ethics, and Economics in the Newer Historical School, Springer Verlag, New York, NY, pp.4-29.

Brouwer, M. (2002), "Weber, Schumpeter and Knight on entrepreneurship and economic development", Journal of Evolutionary Economics, Vol. 12 No. 1/2, pp. 83-105. 
Brubaker, R. (2013), The Limits of Rationality, Routledge, London.

Bukari, K. N. (2016) "A Concomitant of Conflict and Consensus: Case of a Chieftaincy Succession in Ghana", Peace and Conflict Studies: Vol. 23 No. 1, Article 5.

Chenhall, R. H. (2003), "Management control systems design within its organizational context: findings from contingency-based research and directions for the future", Accounting, Organizations and Society, Vol. 28 No. 2-3, pp. 127-168.

Choudhury N. (1988), "The seeking of accounting where it is not: towards a theory of nonaccounting in organizational settings", Accounting, Organizations and Society, Vol. 13 No. 6, pp. 549-57.

Chua, W.F. and Poullaos, C. (1998), "The dynamics of 'closure' amidst the construction of market, profession, empire and nationhood: an historical analysis of an Australian Accounting Association, 1886-1903", Accounting, Organizations and Society, Vol. 23 No. 2, pp. 155-187. Colignon, R. and Covaleski, M. (1991), "A Weberian framework in the study of accounting", Accounting, Organizations and Society, Vol. 16 No. 2, pp. 141-157.

Covaleski, M. A., Dirsmith, M. W. and Sajay, S. (1996), "Managerial accounting research: the contributions of organizational and sociological theories, Journal of Management Accounting Research, Vol. 8, pp. 1-35.

Douglas, M. (1999), Implicit meanings: selected essays in anthropology, $2^{\text {nd }}$ Edition, London and New York: Routledge.

Dyball, M.C., Chua W.F. and Poullaos C. (2006), "Mediating between colonizer and colonized in the American empire: accounting for government monies in the Philippines", Accounting, Auditing and Accountability Journal., Vol. 19, No. 1, pp.47-81.

Egbe, I., Tsamenyi, M. and Sa'id, H. (2012), "A study of the operations of formal and informal controls in a multinational subsidiary in Nigeria", Research in Accounting in Emerging Economies, Vol. 12, pp. 1-29.

Frank, A. G. (1969), Latin America: Underdevelopment or Revolution? Monthly Review Press, New York and London.

Gallhofer S. and Chew A. (2000), "Introduction: accounting and indigenous peoples", Accounting, Auditing \& Accountability Journal, Vol. 13 No. 3, pp. 256-267.

Goddard, A. and Mkasiwa, T. (2016), "New public management and budgeting practices in Tanzanian central government: "struggling for conformance", Journal of Accounting in Emerging Economies, Vol. 6 No. 4, pp. 340-371.

Goddard, A., Assad, M., Issa, S. and Malagila, J. (2016), "The two publics and institutional theory-a study of public sector accounting in Tanzania", Critical Perspectives on Accounting, Vol. 40 October, pp. 8-25.

Grier, B. (1981), "Underdevelopment, modes of production and the states in colonial Ghana", African Studies Review, Vol. 24 No. 1, pp. 21-47.

Guerreiro, R., Pereira, C.A. and Frezzati, F. (2006), "Evaluating management accounting change according to the institutional theory approach: a case study of a Brazilian bank", Journal of Accounting \& Organizational Change, Vol. 2 No. 3, pp. 196-228.

Guha-Khasnobis B, Kanbur R, Ostrom E. (2006), Beyond Formality and Informality, in GuhaKhasnobis, B., Kanbur, R. and Ostrom, E. (Eds), Linking the Formal and Informal Economy. Concepts and Policies, Oxford University Press, Oxford, pp. 1-18.

Guven-Uslu, P., Blaber, Z. and Adhikari, P. (2020), "Boundary spanners and calculative practices", Financial Accountability \& Management, Vol. 36 No. 4, pp. 439-460

Gyimah, R. and Dadebo, M. (2010), Mapping Of Key Governance Reform In Ghana And The Role Of Growing Partnerships, Forestry Commission Ghana.

Hansen, C.P and Lund J.F. (2011), "The political economy of timber taxation: The case of Ghana", Forest Policy and Economics, Vol. 13 No. 8, pp. 630-641. 
Hansen, C.P., Damnyag, L., Obiri, B.D. and Carlsen, K. (2012), "Revisiting illegal logging and the size of the domestic timber market: The case of Ghana", International Forestry Review, Vol. 14 No. 1, pp. 1-11.

Harriss, B. (1978), "Quasi-formal employment structures and behaviour in the unorganized urban economy, and the reverse: Some evidence from South India", World Development, Vol. 6 No. 9-10, pp. 1077-1086.

Hindess, B. and Hirst, P. Q. (1977), Mode of Production and Social Formation: An AutoCritique of Pre-Capitalist Modes of Production, Palgrave Macmillan, UK.

Hopper, T., Lassou, P. and Soobaroyen, T. (2017), "Globalisation, accounting and developing countries", Critical Perspectives on Accounting, Vol. 43 March, pp. 125-148.

Hopper, T., Tsamenyi, M., Uddin, S. and Wickramasinghe, D. (2009), "Management accounting in less developed countries: what is known and needs knowing", Accounting, Auditing \& Accountability Journal, Vol. 22 No.3, pp. 469-514.

Hopwood, A. and Miller, P (1994), Accounting as Social and Institutional Practice, Cambridge University Press, Cambridge.

Hopwood, A.G. (1983), "On trying to study accounting in the contexts in which it operates", Accounting, Organizations and Society, Vol. 8 Nos 2/3, pp. 287-305.

Jayasinghe, K., Adhikari, P., Carmel, S. and Sopanah, A. (2020), "Multiple rationalities of participatory budgeting in indigenous communities: evidence from Indonesia", Accounting, Auditing \& Accountability Journal, Vol. 33 No. 8, pp. 2139-2166.

Jayasinghe, K. and Thomas, D. (2009), "The preservation of indigenous accounting systems in a subaltern community", Accounting, Auditing \& Accountability Journal, Vol. 22 No. 3, pp. 351-378.

Jayasinghe, K. and Wickramasinghe, D. (2007), "Calculative practices in a total institution, Qualitative Research in Accounting and Management, Vol.4 No 3, pp.183-202.

Kalberg, S. (1980), Max Weber's types of rationality: cornerstones for the analysis of rationalization processes in history", The American Journal of Sociology, Vol. 85 No. 5, pp. 1145-117.

Kasanga, K. and Kotey, N.A. (2001), Land Management in Ghana: Building on Tradition and Modernity, IIED, London.

Kattan, F., Pike, R. and Tayles, M. (2007), "Reliance of management accounting under environmental uncertainty: the case of Palestine", Journal of Accounting \& Organizational Change, Vol. 3 No. 3, pp. 227-249.

Kuruppu, C., Adhikari, P., Gunarathna, V., Ambalangodage, D., Perera, P., and Karunarathna, C. (2016), "Participatory budgeting in a Sri Lankan urban council: A practice of power and domination", Critical Perspectives on Accounting, Vol. 41 December, pp. 1-17.

La Ferrara, E. and Milazzo, A. (2017) "Customary Norms, Inheritance, and Human Capital: Evidence from a Reform of the Matrilineal System in Ghana", American Economic Journal: Applied Economics, Vol. 9 No. 4, pp. 166-185.

Lapsley, I., Miller, P. and Steccolini, I. (2020), "The shaping of public services through calculative practices: the roles of accountants, citizens, professionals, and politicians", Financial Accountability \& Management, Vol. 36 No. 4, pp. 343-346

Lund, J.F., Carlsen, K., Hansen, C.P., and Treue, T. (2012), "The political economy of timber governance in Ghana" European Tropical Forest Research Network News, Vol. 15 No. 53, pp.117-127

McLane, R. J. (1993), Land and Local Kingship in Eighteenth-Century Bengal, Cambridge University Press, Cambridge.

Miles, M. and Huberman, A. M. (2002), The Qualitative Researcher Companion, SAGE Publications, New Delhi. 
Miller, P (1998), “The margins of accounting”, European Accounting Review, Vol.7 No. 4, pp. 605-621.

Miller, P. (1994), "Accounting as social and institutional practice: an introduction", in Hoopwood, A. and Miller, P. (Eds.), Accounting as Social and Institutional Practice, Cambridge University Press, Cambridge, pp. 1-39.

Miller, P. (2001), "Governing by numbers: why calculative practices matter", Social Research, Vol. 68 No. 2, pp. 379-396.

Miller, P. and O'Leary, T. (1987), "Accounting and the construction of the governable person", Accounting, Organizations and Society, Vol. 12 No. 3, pp. 235-265.

Ministry of Lands and Natural Resources (2012) Climate Investment Funds, Forest Investment Program, Ghana Investment Plan for the Forest Investment Program, October 2012.

Mody, M., Day, J., Sydnor, S. and Jaffe, W. (2016), "Examining the motivations for social entrepreneurship using Max Weber's typology of rationality", International Journal of contemporary Hospitality Management, Vol. 28 No. 6, pp. 1094-1114.

Ntiamoa-Baidu, Y. (1991), "Conservation of coastal lagoons in Ghana: the traditional approach", Landscape and Urban Planning, Vol. 20 No. 1-3, pp. 41-46.

Nyamori, R., Abdul-Rahaman, A. and Samkin, G. (2017), "Accounting, auditing and accountability research in Africa: recent governance developments and future directions", Accounting, Auditing \& Accountability Journal, Vol. 30 No. 6, pp. 1206-1229.

Ochieng, R.M., Visseren-Hamakers, I.J. and Nketiah K.S. (2013), "Interaction between the FLEGT-VPA and REDD+ in Ghana: Recommendations for interaction management", Forest Policy and Economics, Vol. 32 July, pp.32-39.

Rahaman, A. S., Everett, J. and Neu, D. (2007), "Accounting and the move to privatize water services in Africa", Accounting, Auditing \& Accountability Journal, Vol. 20 No. 5, pp. 637670.

Rahaman, A.S. (2010), "Critical accounting research in Africa: whence and whither", Critical Perspectives on Accounting, Vol. 21 No. 5, pp. 420-427.

Rey, P. (1971), Colonialisme, Neo-Colonialisme, et Transition au Capitalisme, Maspero, Paris.

Sikka, P. (2015), "The hand of accounting and accountancy firms in deepening income and wealth inequalities and the economic crisis: some evidence", Critical Perspectives on Accounting, Vol. 30 July, pp. 46-62.

Su Leen Tan, S. and Woodward, D.G. (2005), "The management accounting implications of trust: An analysis of three applications and specification of a possible research agenda", Journal of Applied Accounting Research, Vol. 7 No. 3, pp. 27-77.

Tales, P.R. and Sofias, S. (2007), "Intellectual capital, management accounting practices and corporate performance: perceptions of managers", Accounting, Auditing \& Accountability Journal, Vol. 20 No. 4, pp.522-48.

Tsamenyi, M., Onumah, J. and Tetteh-Kumah, E. (2010), "Post-privatization performance and organizational changes: Case studies in Ghana", Critical Perspectives on Accounting, Vol. 21 No. 5, pp.428-442

Uddin, S. (2009), "Rationalities, domination and accounting control: A case study from a traditional society", Critical Perspectives on Accounting, Vol. 20 No. 6, pp.782-794.

Uddin, S. and Choudhury, J., (2008), "Rationality, traditionalism and the state of corporate governance mechanisms", Accounting, Auditing \& Accountability Journal, Vol. 21 No. 7, pp. 1026-1051.

Uddin, S., Siddiqui, J. and Islam, M. (2018), "Corporate Social Responsibility Disclosures, Traditionalism and Politics: A Story from a Traditional Setting”, Journal of Business Ethics, Vol. 151 No 2, pp. 409-428. 
Van Helden, J. and Uddin, S. (2016), "Public sector management accounting in emerging economies: A literature review", Critical Perspectives on Accounting, Vol. 41 December, pp. 34-62.

Vollmer, H. (2003), "Bookkeeping, accounting, calculative practice: the sociological suspense of calculation”, Critical Perspectives on Accounting, Vol. 14 No. 3, pp. 353-381.

Walker, S.P. and Llewellyn, S. (2000), "Accounting at home: some interdisciplinary perspectives", Accounting, Auditing \& Accountability Journal, Vol. 13 No. 4, pp. 425-49.

Weber, M. (1948). "Capitalism \& Rural Society in Germany" (Chapter 14) and "India: The Brahman \& Castes" (Chapter 16. In Gerth H.H. and Mills C.W. (eds), From Max Weber: Essays in Sociology, Oxford University Press, New York.

Weber, M. (1958), The Protestant Ethic and the Spirit of Capitalism, Scribner, New York.

Weber, M. (1961), General Economic History, Collier Books, New York.

Weber, M. (1968), Economy and Society: An Outline of Interpretive Sociology, Bedminster, New York.

Wickramasinghe, D. and Alawattage, C. (2007), Management Accounting Change Approaches and Perspectives, Routledge, New York.

Wickramasinghe, D. and Hopper, T. (2005), "A cultural political economy of management accounting controls: a case study of textile mile in a traditional Sinhalese village", Critical Perspectives on Accounting, Vol. 16 No.4, pp.473-503.

World Bank (2012), Gender dimensions of artisanal and small-scale mining: a rapid assessment toolkit, Washington DC: Online

http://documents.worldbank.org/curated/en/2012/01/15940643/gender-dimensions-

artisanalsmall-scale-mining-rapid-assessment-toolkit.

Yeboah, E. and Shaw, D. (2013) "Customary land tenure practices in Ghana: examining the relationship with land-use planning delivery”, International Development Planning Review, Vol. 35 No. 1, pp. 21-39.

Yin, R. K. (2003), Case Study Research Design and Methods: Applied Social Research Methods Series Volume 5, Third Edition, Sage Publications, London.

Young, D. (2017), How much do communities get from logging? Social obligations in the logging sector Cameroon, Ghana, Liberia and Republic of Congo, Fern, Fern Office, UK. Available at: https://www.fern.org/fileadmin/uploads/fern/Documents/fern\%20how\%20much.pdf. 


\section{FIGURES}

Figure 1: The Formal Organisational Structure of TimberCo Ghana

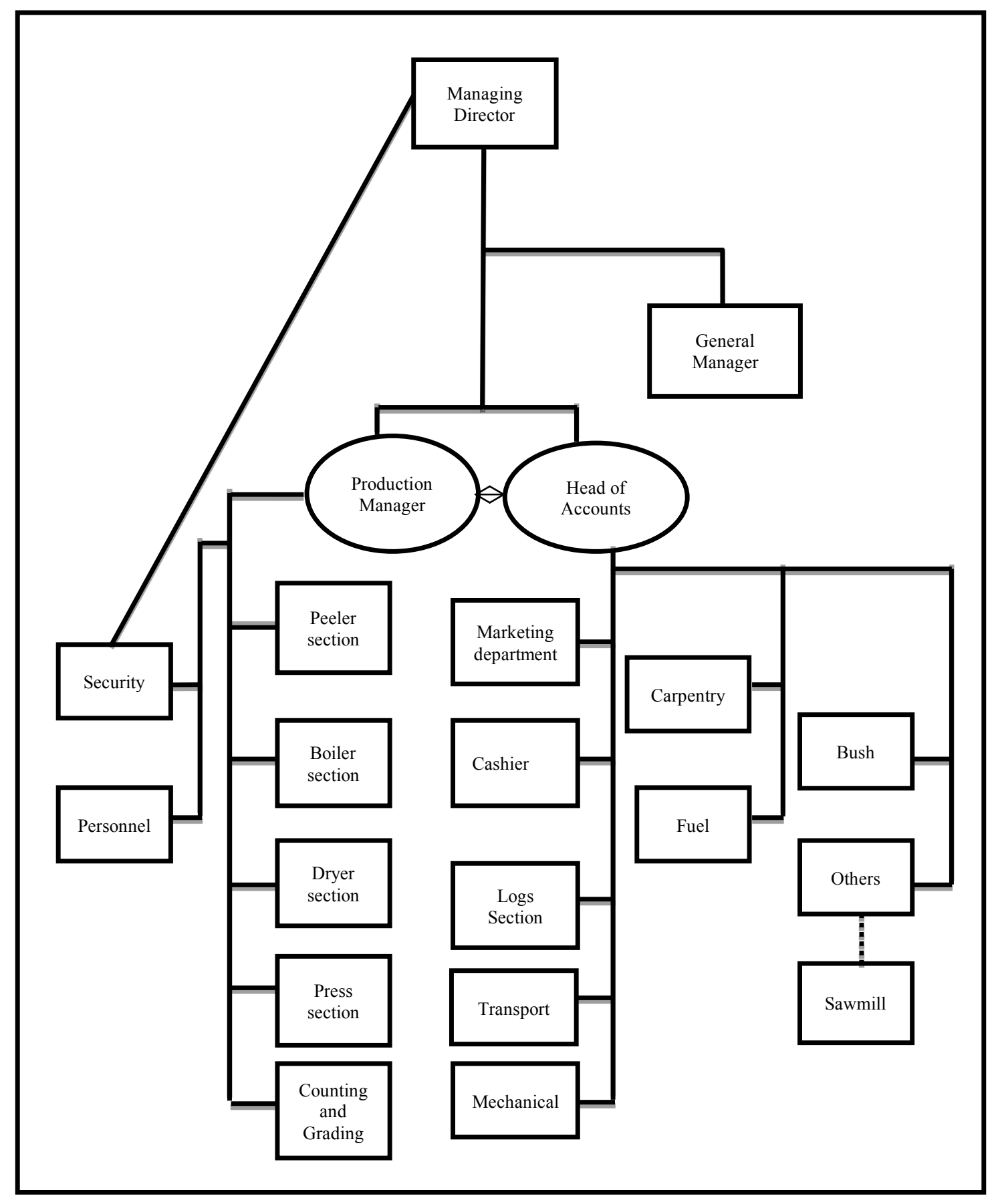


Figure 2: Representation of the Organisational Structure in Practice ${ }^{2}$

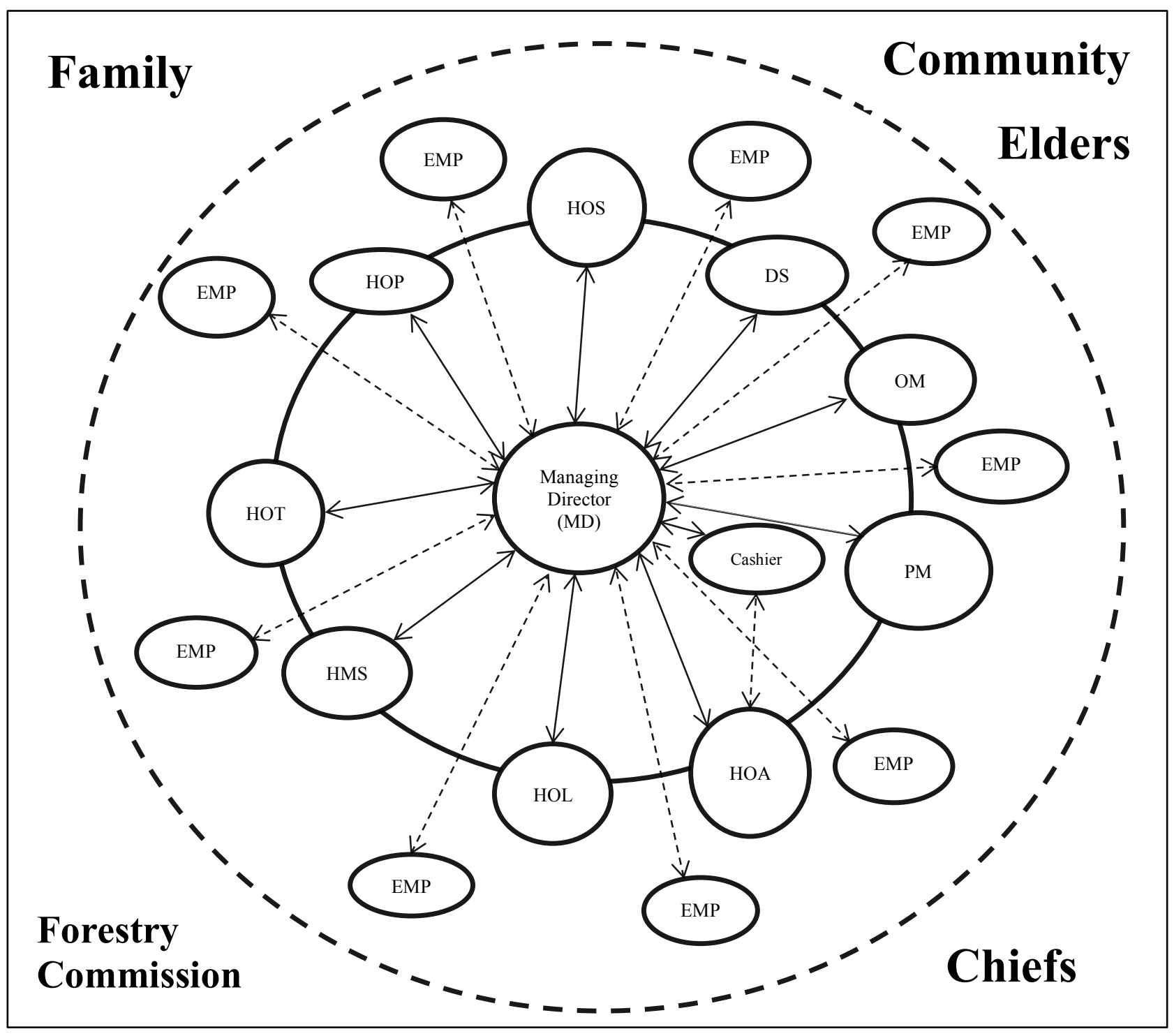

${ }^{2}$ Abbreviations: departmental employees(EMP); Head of Security (HOS); Head of Personnel (HOP); Head of Transport(HOT); Head of Logs (HOL); Head of Accounts(HOA); Production Manager(PM); Other Managers(OM); Head of Marketing and Sales(HMS); Departmental Supervisors (DS); Cashier(Cashier). 
TABLES

Table 1: Activity Structure of the Ghana Timber Industry

\begin{tabular}{|l|c|c|c|c|}
\hline \multirow{2}{*}{ Activity Area } & \multicolumn{4}{c|}{ Number of Firms } \\
\cline { 2 - 5 } & $\mathbf{1 9 9 1}$ & $\mathbf{1 9 9 4}$ & $\mathbf{1 9 9 8}$ & $\mathbf{2 0 0 1}$ \\
\hline Primary (Logging) & 200 & 250 & 250 & 250 \\
\hline Secondary & & & 140 & 194 \\
\hline Sawmilling & 100 & 110 & 25 & 32 \\
\hline Veneering & 13 & 15 & 14 & 14 \\
\hline Plymilling & 9 & 9 & & 40 \\
\hline Tertiary & & & 6 & 14 \\
\hline Furniture(Medium/Large) & 40 & 40 & 2 & 2 \\
\hline Flooring & 4 & 6 & 6 & 2 \\
\hline Chip/Particle board & 1 & 1 & 4 & 6 \\
\hline Doors (Medium/large) & 4 & 6 & 22 & 47 \\
\hline Toys & 2 & 4 & & \\
\hline Profile Boards/Mouldings & 5 & 12 & & \\
\hline
\end{tabular}

Source: Adapted from Bank of Ghana (2004), Research Department Document. 
Table 2: Timber business royalty payments

\begin{tabular}{|l|c|c|}
\hline Proportion of payments made to: & $\begin{array}{c}\text { Area-based cash } \\
\text { payment } \\
\text { (Annual rent) }\end{array}$ & $\begin{array}{c}\text { Volume-based cash } \\
\text { payment } \\
\text { (Stumpage fee) }\end{array}$ \\
\hline The Forestry Commission & $0 \%$ & $50 \%$ \\
\hline $\begin{array}{l}\text { The office of the Administrator of Stool } \\
\text { Lands }\end{array}$ & $10 \%$ & $5 \%$ \\
\hline Of the remainder: & $22.50 \%$ & $11.25 \%$ \\
\hline The relevant Stool & $18 \%$ & $9 \%$ \\
\hline The relevant Traditional Authority & $49.50 \%$ & $24.75 \%$ \\
\hline The relevant District Assembly & & \\
\hline
\end{tabular}

Notes: Annual rent per hectare per year is Ghana Cedis 0.12 (or USD 0.03) for forest reserves and Ghana Cedis 0.1 (or USD 0.025) for off-forest areas. Stumpage fee is computed as tree volume multiplied by timber price multiplied by stumpage rate. Timber price is $35 \%$ of Free On Board value of equivalent air-dried lumber. Stumpage rate is determined by the Minister in consultation with the Forestry commission and Administrator of Stool Lands.

Source: Adapted from Young (2017). 


\section{APPENDICES}

Appendix 1: Table of interviewees

\begin{tabular}{|c|c|c|c|c|}
\hline Departments & $\begin{array}{c}\text { Categories } \\
(\text { Coded names) }\end{array}$ & $\begin{array}{l}\text { Sub-categories } \\
\text { (Coded names) }\end{array}$ & $\begin{array}{l}\text { On (or } \\
\text { Off) site }\end{array}$ & Total \\
\hline Accounts/Finance & Head of Accounts (HOA) & $\begin{array}{l}1 \text { st Accounts Supervisor } \\
\text { (ASI), 2nd Accounts } \\
\text { Supervisor (ASII) }\end{array}$ & On & 3 \\
\hline Production & Production Manager (PM) & $\begin{array}{l}\text { Boiler Supervisor (BS), } \\
\text { Pillar Supervisor (PS), } \\
\text { Dryer Supervisor (DS), } \\
\text { Press Supervisor (PS), } \\
\text { Grading/Counting } \\
\text { (GCS) }\end{array}$ & On & 6 \\
\hline Sales and Marketing & $\begin{array}{l}\text { Head of Marketing and } \\
\text { Sales (HMS) }\end{array}$ & $\begin{array}{l}\text { Marketing Supervisor I } \\
\text { (MSI) }\end{array}$ & On & 2 \\
\hline Logs & Head of Logs (HOL) & & On & 1 \\
\hline Transport & Head of Transport (HOT) & $\begin{array}{l}\text { Transport Supervisor I } \\
\text { (TS1) }\end{array}$ & On & 2 \\
\hline Forest Operations & $\begin{array}{l}\text { Head of Forest Operations } \\
\text { (HFO) }\end{array}$ & & On & 1 \\
\hline Carpentry & Head of Carpentry (HOC) & & On & 1 \\
\hline Engineering & $\begin{array}{l}\text { Head of Mechanical } \\
\text { (eHOM), Head of Electrical } \\
\text { (HOE) }\end{array}$ & Supervisor I (eMS) & On & 3 \\
\hline Fuel & & Supervisor (FS) & On & 1 \\
\hline Other supervisors & Other supervisors (OS) & & On & 6 \\
\hline General employees & General Employees (GE) & & On & 15 \\
\hline Security & Head of Security (HOS) & Security Supervisor (SS) & On & 2 \\
\hline Ex-employees & Ex-employees (ExEMP) & & Off & 3 \\
\hline Community & Community (COMMTY) & & Off & 3 \\
\hline $\begin{array}{l}\text { Ministry of Lands and } \\
\text { Natural Resources }\end{array}$ & Director for Timber (DFT) & & Off & 1 \\
\hline Regional Forestry & Regional Director (RFD) & & Off & 1 \\
\hline $\begin{array}{l}\text { Faculty of Forest } \\
\text { Resources }\end{array}$ & Lecturers (LI, LII) & & Off & 2 \\
\hline Trade Union & District (TU) & & Off & 3 \\
\hline Total & & & & 56 \\
\hline
\end{tabular}




\section{Appendix 2: Internal and external documents}

\begin{tabular}{|l|l|}
\hline Documents & Source \\
\hline Panel A: Internal documents & \\
\hline $\begin{array}{l}\text { Company Registration Certification } \\
\text { Document }\end{array}$ & Information board \\
\hline Logs requisition documents & Logs department \\
\hline Budget reports & Production and Accounts department \\
\hline Production reports & Production department \\
\hline Financial accounts & Accounts/Finance department \\
\hline Organisational charts & Information board \\
\hline Panel B: External documents & \\
\hline $\begin{array}{l}\text { Bank of Ghana (2004) Report on } \\
\text { Ghana's Timber Industry }\end{array}$ & Bank of Ghana Research Department Document Vol.2 No.1 \\
\hline $\begin{array}{l}\text { Ministry of Lands and National } \\
\text { Resources document on Forest } \\
\text { Investment Program }\end{array}$ & $\begin{array}{l}\text { Ministry's document: } \\
\text { https://www.climateinvestmentfunds.org/sites/cif_enc/files/fip_5_ghana. } \\
\text { pdf }\end{array}$ \\
\hline $\begin{array}{l}\text { The Forestry Commission of Ghana } \\
\text { reports }\end{array}$ & \begin{tabular}{l} 
The Forestry Commission of Ghana: https://www.fcghana.org/ \\
\hline
\end{tabular} \\
\hline
\end{tabular}

